BLS 33, No 1 2007. DOI: http://dx.doi.org/10.3765/bls.v33i1.3517

(published by the Berkeley Linguistics Society and the Linguistic Society of America)

\title{
Disambiguation Strategies in Across-the-Board Wh-Questions
}

\author{
BARBARA CITKO \\ University of Washington
}

\section{Ambiguity of ATB Wh-Questions}

Across-the-board wh-questions are considered to be ambiguous between so-called single individual and pair list readings. The two readings are best distinguished by the types of answers such questions allow. For example, (1a) can either be a question about a single quantity of books, or about two distinct quantities, as shown by the availability of the answers in (1b) and (1c). ${ }^{1}$

(1) How many books $s_{i}$ did John like $t_{i}$ and Mary dislike $t_{i}$ ?

b. Seven.

c. John liked 5 books and Mary disliked 8 books.

On the copy theory of movement of Chomsky (1995), which treats movement as a sequence of three operations (Copy, Merge, and Delete), the availability of these two interpretations can be reduced to the issue of which copy (or copies) are deleted at LF. The two possible derivations of (1a), corresponding to the two interpretations, are schematized in (2a-c) and (3a-c), respectively. Both involve deletion of the lower two copies at PF, illustrated in (2b) and (3b). The two differ, however, with respect to which copies delete at LF. If the two lower copies delete, the result is a single individual reading, given in (2c), in which the fronted whphrase has wide scope with respect to the conjunction. If the higher copy deletes,

\footnotetext{
${ }^{1}$ There is a preference for single individual readings, which has to do with the blocking effect induced by the availability of CP coordination alternative, given in (i), which is unambiguously interpreted as pair list.

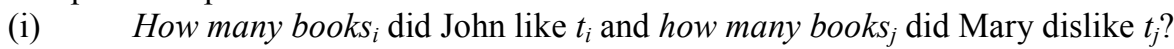

The availability of pair list readings in ATB questions becomes more apparent in examples of the following sort:

(ii) Which of his victims $s_{i}$ did Bill kill $t_{i}$ on Tuesday and Fred kill $t_{i}$ on Wednesday?

(iii) Bill killed his first victim and Fred killed his second.

(iv) Bill killed Bruno and Fred killed Arno.

(Munn 1999:422)
} 


\section{Barbara Citko}

the result is a pair list reading, given in (3c), in which the wh-phrase has narrow scope with respect to the conjunction.

(2) a. Copy and Merge how many books in [Spec,CP]:

[CP How many books did [\&P [TP John like how many books] and [TP Mary dislike how many books? ] ] ]

b. Delete lower copies at PF:

[СР How many books did [\&P [те John like how many books] and [TP Mary dislike how many books? ] ] ]

c. Delete lower copies at LF:

[CP How many books did [\&P [TP John like how many books] and [тр Mary dislike how many books? ] ] ] (single individual reading)

(3) a. Copy and Merge how many books in [Spec,CP]:

[CP How many books did [\&P [тP John like how many books] and [TP Mary dislike how many books? ] ] ]

b. Delete lower copies at PF:

[CP How many books did [\&P [TP John like how many books] and [TP Mary dislike how many books? ] ] ]

c. Delete upper copy at LF:

[CP How many books did [\&P [TP John like how many books] and [тР Mary dislike how many books? ] ] ]

(pair list reading)

This is by no means the only way to account for the ambiguity of ATB questions. However, since my main focus in this paper is not on what allows both readings, but on what factors disambiguate toward one reading over the other, I will refrain from comparing the copy deletion based account schematized here to more semantic alternatives, such as Munn's (1999) account, which assimilates pair list readings to functional readings, or Gawron and Kehler's (2003) account, which derives pair list readings from the presence of an implicit RESP operator, thus assimilating them to coordinate structures containing the adverb respectively.

Instead, I will examine two factors that disambiguate toward either a single individual or a pair list interpretation of ATB questions. One involves the choice of the coordination strategy, and the other one left branch extraction. I will focus on Polish, a West Slavic language, which differs from English in three relevant respects. First, unlike English, it allows the correlative coordination both ... and with clausal conjuncts: ${ }^{2} 3$

${ }^{2}$ Polish is not unique in this respect. Johannessen (2005) shows that Norwegian, Icelandic, Greek, and Dutch behave similarly.

${ }^{3}$ All correlative coordination strategies in Polish involve repetition of the relevant conjunction:

(i) $\quad i \quad$ Jan $i \quad$ Maria and Jan and Maria

'both Jan and Maria' 
b. I Jan się śmieje i Maria się śmieje. and Jan REFL laughs and Maria REFL laughs

'Jan laughs and Maria laughs'

Second, unlike English, Polish allows left branch extraction:

$$
\begin{array}{ll}
\text { a. } & \text { * How many } y_{i} \text { did you read } t_{i} \text { books? } \\
\text { b. } & \text { Ile } e_{i} \quad \text { ksiażek } t_{i} \text { przeczytałaś? } \\
& \text { how-many books read.2sg } \\
\text { 'How many books have you read?' }
\end{array}
$$

And third, Polish has an 'extra' conjunction marker, the so-called contrastive conjunction, which creates extra interpretive possibilities in ATB questions. The conjunction in question is $a$, glossed as and $d_{C}$, which is distinguished from the consecutive conjunction $i$, which marks temporal sequence. English uses the same conjunction to express both contrast and temporal sequence, which has been shown by Malchukov (2004) to be quite common from a typological perspective. ${ }^{4}$

a. $\quad$ Poszedł do sklepu $\boldsymbol{i} / * \boldsymbol{a}$ kupił chleb. went to store and and ${ }_{C}$ bought bread 'He went to the store and bought some bread.'

b. Jan poszedł do sklepu $a / *_{i}$ Maria pojechała do kina. Jan went to store and $/$ and Maria went to cinema 'Jan went to the store and Maria to the movies.'

The contrastive nature of the Polish conjunction $a$ is further shown by the fact that it is required in cases of coordinate ellipsis, such as gapping or right node raising. ${ }^{5}$

(ii) albo Jan albo Maria or Jan or Maria 'either Jan or Maria'

(iii) ani Jan ani Maria nor Jan nor Maria 'neither Jan nor Maria'

${ }^{4}$ In cases such as the ones given in (i-ii), in which there is no overtly expressed contrast, there is an implicit one.

(i) Znikał na całe tygodnie, $\boldsymbol{a}$ nawet miesiące. disappeared for whole weeks, and even months 'He would disappear for whole weeks, and even months.' 


\section{Barbara Citko}
a. Maria czyta książki $\boldsymbol{a} / \boldsymbol{*}_{\boldsymbol{i}} \quad$ Ania opowiadania.

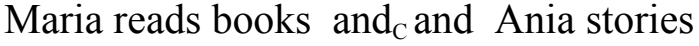 'Maria reads books and Ania stories.'
b. Jan przeczytał $\boldsymbol{a} / *_{\boldsymbol{i}} \quad$ Maria zrecenzjonowała ten artykuł. Jan read $\quad \operatorname{and}_{\mathrm{C}}$ and Maria reviewed this article 'Jan read and Maria read this article.'

In the remainder of this paper, I turn to the issue of how the choice of coordination strategy and left branch extraction affect the interpretation of ATB questions. I will proceed as follows. In Sections 1 and 2, I will show that correlative coordination disambiguates toward a single individual reading and left branch extraction disambiguates toward a pair list reading. And in Section 3, I will propose an account which derives these two generalizations from two independent factors: the status of the correlative both as a focus particle, and the fact that focus particles cause intervention effects.

\section{Conjunction Strategies in Polish ATB Questions}

All three conjunctions strategies discussed in the previous section, namely consecutive, contrastive, and correlative conjunctions, are allowed in Polish ATB questions. However, they result in different interpretations. Questions with consecutive and correlative conjunctions are disambiguated toward a single individual reading, as shown in (8) and (9), whereas questions with a contrastive conjunction allow both readings, as shown in (10).
a. Ile artykułów $_{i} \boldsymbol{i}$ Maria napisała $t_{i} \boldsymbol{i}$ Ania how-many articles and Maria wrote and Ania przeczytała $t_{i}$ ?
read

'How many articles did Maria write and Ania read?'

b. Pięć.

five

c. \# Maria napisała 5 artykułów i Ania przeczytała 9 artykułów. Maria wrote 5 articles and Ania read 9 articles 'Maria wrote 5 articles and Ania read 9 articles.'

\footnotetext{
a. Ile artykułów $w_{i}$ Maria napisała $t_{i} \boldsymbol{i}$ Ania przeczytała $t_{i}$ ? how-many articles Maria wrote and Ania read 'How many articles did Maria write and Ania read?'

b. Pięć. five

c. \# Maria napisała 5 artykułów $\boldsymbol{i}$ Ania przeczytała 9 artykułów. Maria wrote 5 articles and Ania read 9 articles 'Maria wrote 5 articles and Ania read 9 articles.'
} 
Scope Disambiguation Strategies in ATB Wh-Questions

(10) a. Ile artykułów $w_{i}$ Maria napisała $t_{i} \boldsymbol{a}$ Ania przeczytała $t_{i}$ ? how-many articles Maria wrote and ${ }_{C}$ Ania read 'How many articles did Maria write and Ania read?'

b. Pięć.

five

c. Maria napisała 5 artykułów $\boldsymbol{a}$ Ania przeczytała 9 artykułów. Maria wrote 5 articles and $_{C}$ Ania read 9 articles 'Maria wrote 5 articles and Ania read 9 articles.'

In cases in which only a pair list reading is felicitous, such as the one in (11a-b), only a contrastive conjunction is possible: ${ }^{6}$

a. Ile ze swoich ofiar Jan zabił $t_{i}$ w piątek $\boldsymbol{a} / *_{\boldsymbol{i}}$ Tomek how-many of REFL victims Jan killed on Friday and $/$ and Tom zamordował $t_{i} \mathrm{~W}$ sobotę?

murdered on Saturday

'How many of his victims did Jan kill on Friday and Tom murder on Saturday?'

b. * Ile ze swoich ofiar $\boldsymbol{i}$ Jan zabił w piątek $\boldsymbol{i}$ how-many of REFL victims and Jan killed on Friday and Tomek zamordował w sobotę?

Tom murdered on Saturday

The generalization that emerges from the data discussed in this section is that correlative and consecutive coordination strategy block pair list readings in ATB wh-questions. In the next section, I turn to the effects of left branch extraction on the interpretation of ATB questions.

\section{Left Branch Extraction in ATB Wh-Questions}

As is well-known since Ross 1967, Slavic languages allow violations of the Left Branch Condition in simple wh-questions. An example from Polish is given in (12a). It contrasts in grammaticality with (12b), which might suggest that left branch extraction is impossible in ATB questions.

a. $\quad$ Ile $e_{i} \quad$ Maria napisała $t_{i}$ artykułów?

how-many Maria wrote articles

'How many articles did Maria write?'

\footnotetext{
${ }^{6}$ These examples are modeled upon Munn's (1999) English examples.
} 


\title{
Barbara Citko
}

\author{
b. Ile $_{i} \quad$ Maria napisała $t_{i}$ artykułów $\boldsymbol{i} / \boldsymbol{a}$ Ania \\ how-many Maria wrote articles and/and ${ }_{C}$ Ania \\ przeczytała $t_{i}$ artykułów? \\ read articles
}

'How many articles did Maria write and Ania read?'

However, this is only apparent. In Citko 2006, I showed that ATB LBE is grammatical as long as long as the 'remnants' inside the second conjunct are distinct from their correspondents inside the first conjunct. (12b) thus becomes grammatical if the stranded nominal inside the second conjunct is replaced with one that is distinct from its correspondent inside the first conjunct.

(13) Ile $e_{i} \quad$ Maria napisała $t_{i}$ artykułów $\boldsymbol{a}$ Ania przeczytała $t_{i}$ opowiadań? how-many Maria wrote articles and ${ }_{C}$ Ania read stories How many articles did Maria write and how many stories did Ania read?

What is interesting is the fact that left branch extraction in ATB questions is only possible with a contrastive conjunction. This is shown by the contrast between the grammatical example in (13) above, and the ungrammatical ones in (14a-b) below, involving a consecutive and a correlative conjunction, respectively.
a. *Ile $_{i} \quad$ Maria napisała $t_{i}$ artykułów $\boldsymbol{i}$ Ania przeczytała $t_{i}$ how-many Maria wrote articles and Ania read opowiadań?
stories
'How many articles did Maria write and how many stories did Ania read?'
b. *lle $_{i} \quad \boldsymbol{i}$ Maria napisała $t_{i}$ artykułów $\boldsymbol{i}$ Ania how-many and Maria wrote articles and Ania przeczytała $t_{i}$ opowiadań?
read stories
'How many articles did Maria write and how many stories did Ania read?'

Furthermore, left branch extraction forces narrow scope interpretation. The only possible answer to the question in (13) above involves two distinct quantities of books.
a. \# Pięć.
five
b. Maria napisała 5 artykułów a Ania preczytała 10 esejów. Maria wrote 5 articles and $_{C}$ Ania read 10 essays 'Maria wrote 5 articles and Ania read 10 essays.'


In this respect, ATB questions with left branch extraction (and a contrastive conjunction) differ from their pied-piped counterparts, which allow both readings (as shown in (10a-c) above). This raises the question of why left branch extraction forces narrow scope interpretation. Two other questions that emerge from the discussion so far are why correlative coordination blocks left branch extraction (as shown in (14b) above), and why correlative coordination blocks narrow scope reading (as shown in (10a-c) above). In what follows, I will show that the answers to these questions are related, and follow from the status of correlative coordination particles, coupled with independent properties of focus particles.

\section{Toward an Account}

There are two crucial ingredients to my proposal. The first one involves the semantic contribution of the correlative particle both (and its Polish counterpart $i$ 'and'). In this respect, I follow Hendriks (2001) and Johannessen (2005), who analyze correlative particles as focus particles. They point to the fact that in English both behaves like only in (at least) two respects. Both both and only can be separated from the constituents they are associated with, as shown in (16a-b).

a. These circumstances proved fortunate both for [myself and Augustus]. (Hendriks 2001:4)

b. These circumstances proved fortunate only for MYSELF.

Furthermore, both are incompatible with clauses:

a. $\quad *$ Both it rains and it snows.

b. * Only it rains.

This prohibition is not universal, as shown by the grammatical status of the Polish counterparts of the English examples in (17a-b).

$$
\begin{array}{ll}
\text { a. } & I \text { pada deszcz } i \text { pada śnieg } \\
& \text { and falls rain and falls snow } \\
\text { 'It both rains and snows.' } \\
\text { b. Tylko pada deszcz. } \\
\text { only falls rain } \\
\text { 'It only rains.' }
\end{array}
$$

The second crucial ingredient in my proposal involves an independent fact that focus particles cause intervention effects (Beck 2006, Kim and Beck 1997, Pesetsky 2000, among others). A typical configuration that gives rise to intervention effects is given schematically in (19a). Typical interveners, which can vary from language to language, are given in (19b). The suggestion I would like to make is that the focus particle both also belongs to the class of interveners. 


\section{Barbara Citko}

a. $\quad *$ A Intervener $\mathrm{B}$

b. only, even, also, not, (almost) every, no, most, few (and other nominal quantifiers), always, often, never (and other adverbial quantifiers), both

There are three distinct environments that show intervention effects, depending on the nature of A and B in (19a). The first one involves wh-in-situ languages, in which the intervener blocks the relationship between a wh-pronoun in situ and its licensing complementizer. In the examples that follow, the interveners are in italics, and the elements whose relationship is blocked are in bold.

$\mathrm{C} \quad$ Intervener $\mathrm{WH}$ (wh-in-situ)

a. * Lili-yum eete pustakam-aane waayikk-ate? Lili-also which book-be read-NOM 'Which book did Lili, too, read?'

c. * Hotondo dono hito-mo nani-o yonda no? almost every person what-ACC read Q 'What did almost every person read?'

d. ?*Zhiyou Lili kan-le na-ben shu? only Lili read-asp which-cl book 'Which book did only Lili read?'

The second case of intervention involves multiple wh-questions in languages which front only one wh-phrase overtly. Here the intervention effect concerns the relationship between the two wh-phrases. ${ }^{7}$

$\mathrm{WH}_{1} \quad$ Intervener $\quad \mathrm{WH}_{2}$ (multiple wh-questions)

a. * Wen hat niemand wo gesehen?

[Ger] whom has nobody where seen 'Where did nobody see whom?'

b. * Wie heeft niemand aan wie voorgesteld? who has nobody to who introduced 'Who did nobody introduce to whom?'

(Beck 2006:7)

\footnotetext{
${ }^{7}$ The situation is a little more complex in English, which show intervention effects only in Dlinked wh-questions violating superiority, as shown by the ontrast between (i) and (ii) (from Pesetsky 2000)

(i) Who did only John introduce to whom?

(ii) ?? Which boy did only Mary introduce which girl to $t_{i}$ ?
} 
And the third one, which is the one that is going to be most relevant for our purposes, involves so-called discontinuous (or split) wh-phrases, in which the relationship between two parts of a single wh-phrase is blocked by an intervening quantificational element. $^{8}$

$\mathrm{WH}_{1} \quad$ Intervener $\quad \mathrm{WH}_{1}$

(discontinuous wh-phrases)

[Ger]
a. $\quad * \mathbf{W e n}_{i}$ hat keine Studentin
$t_{i}$ von den Musikern getroffen?

whom has no student of the musicians met

'Which of the musicians did no student meet?'

b. \# Koho ${ }_{i}$ málo studentù vidilo $t_{i} \mathbf{z}$ muzikantů? whom few students saw from musicians 'Who from the musicians did few students see?

(Kucerova, in press)

With this background on intervention, we can explain the effects of correlative coordination on the interpretation of ATB wh-questions. The first question I want to address here is why narrow scope reading is blocked by the presence of the correlative marker. The relevant example is repeated below.
a. $\quad$ Ile
artykułów
$\boldsymbol{i}$ Maria napisała
$t_{i} \boldsymbol{i}$ Ania
przeczytała $t_{i}$ ?
read
'How many articles did both Maria write and Ania read?'
b. Pięć.
five
c. \# Maria napisała 5 artykułów i Ania przeczytała 9 artykułów. Maria wrote 5 articles and Ania read 9 articles 'Maria wrote 5 articles and Ania read 9 articles.'

The most straightforward syntactic explanation for the availability of narrow scope reading involves interpretation of the ATB extracted wh-phrase in a reconstructed position. In the case at hand, however, reconstruction is blocked by the correlative marker. Given the fact that the correlative marker is a focus particle, the lack of narrow scope reading becomes a straightforward case of an interven-

${ }^{8}$ Corresponding examples in which the nominal is pied-piped are fine:

(i) Wen von den Musikern ${ }_{i}$ hat keine Studentin $t_{i}$ getroffen?

whom of the musicians has no student met

'Which of the musicians did no student meet?'

(ii) Koho z muzikantů ${ }_{i}$ vidìlo málo studentù $t_{i}$ ?

(Beck 1996:3-4)

whom from musicians saw few students

'Who from the musicians did few students see?' 


\section{Barbara Citko}

tion effect, a covert counterpart of the overt cases given in (21) above. The correlative marker intervenes between the interrogative complementizer and the reconstructed wh-phrases, as shown in (24a-b).
a. How many articles did both Maria write how many articles and Anna read how many articles?
b. $\mathrm{C}$ BOTH how many articles

We have also seen above that left branch extraction is blocked by an intervening correlative focus particle, as shown by the ungrammatical status of (25).

* Ile $e_{i} \quad \boldsymbol{i}$ Maria napisała $t_{i}$ artykułów $\boldsymbol{i}$ Ania
how-many and Maria wrote articles and Ania
przeczytała $t_{i}$ esejów?
read essays
'How many articles did Mary write and how many essays did Anna read?

This also becomes a straightforward case of an intervention effect, parallel to the one illustrated in (22) above. The two parts of a wh-phrase (the how many question part and its nominal complement) are separated by the focus particle both, which is what induces an intervention effect.
a. how many both Maria wrote articles and Ania read essays
b. how-many BOTH articles/essays

So far I have explained why correlative coordination blocks narrow scope and left branch extraction. These two are obviously related, as they involve the similar (if not identical) configurations at LF. I have not yet explained why consecutive coordination in Polish induces the same intervention effect (as shown by the lack of a pair list reading in (9) above), and why only contrastive coordination allows narrow scope reading. While a complete consideration of these issues goes beyond the scope of this paper, let me in conclusion offer some suggestions. One way of explaining the lack of pair list readings with consecutive coordination would involve a covert focus particle, akin to the overt both in correlative coordinate structures.

The correlation between the availability of pair list readings and the use of a contrastive conjunction, on the other hand, can be attributed to the lexical properties of the contrastive conjunction. It requires contrast between the two conjuncts. A pair list reading, which results in two distinct answers, is one way of satisfying this requirement. Alternatively, it can be satisfied by focusing the verbs or the subjects, which makes a single individual reading possible. These two possibilities are illustrated in (27-28). 
Scope Disambiguation Strategies in ATB Wh-Questions

(27)
a. Ile artykułów $w_{i}$ Maria napisała $t_{i}$ a Ania how-many articles Maria wrote and $_{C}$ Ania przeczytała $t_{i}$ ?
read
'How many articles did Maria write and Ania read?'
b. Maria napisała 5 artykułów i Ania przeczytała 9 artykułów. Maria wrote 5 articles and Ania read 9 articles 'Maria wrote 5 articles and Ania read 9 articles.'
a. Ile artykutów $w_{i}$ Maria NAPISALA $t_{i} \boldsymbol{a}$ Ania how-many articles Maria wrote $\quad \operatorname{and}_{\mathrm{C}}$ Ania PRZECZYTAŁA $t_{i}$ ?
read
'How many articles did Maria WRITE and Ania READ?'
b. Pieć.
five

\section{Conclusion}

To conclude briefly, I have examined in this paper two factors that affect the interpretation of ATB questions. One was the choice of a coordination strategy (consecutive, contrastive, or correlative), and the other one was left branch extraction. I have shown that correlative coordination forces wide scope reading and blocks left branch extraction. I have argued that this effect of correlative coordination can be attributed to the status of the correlative both as a focus particle, combined with an independent observation that focus particles cause intervention effects. Consequently, I have shown that the incompatibility of pair list readings and left branch extraction with correlative coordination is yet another instance of an intervention effect.

\section{References}

Beck, Sigrid. 2006. Intervention Effects Follow from Focus Interpretation. Natural Language Semantics 14:1-56.

Beck, Sigrid, and Shin-Sook Kim. 1997. On Wh- and Operator Scope in Korean. Journal of East Asian Linguistics 6:339-384.

Chomsky, Noam. 1995. The Minimalist Program. Cambridge: MIT Press.

Citko, Barbara. 2006. On the Interaction Between ATB Wh-Movement and Left Branch Extraction. Syntax 9:225-247.

Frajzyngier, Zygmunt. 1985. Propositional Characterization of Categories. In S. DeLancey and R.S. Tomlin, eds., Proceedings of the First Annual Meeting of the Pacific Linguistics Conference, 108-119. Eugene: Department of Linguistics, University of Oregon.

Gawron, Jean Mark, and Andrew Kehler. 2003. Respective Answers to Coordinated Questions. In R. B. Young and Y. Zhou, eds. Proceedings of the Thir- 


\section{Barbara Citko}

teenth Conference on Semantics and Linguistic Theory. Ithaca: CLC Publications.

Hankamer, Jorge. 1971. Constraints on Deletion in Syntax. Ph. diss., Yale University.

Hendriks. 2001. Edgar Allan Poe and the Case of the Misbehaving Coordinators: 'either', 'both', and 'neither' in Coordinate Structures. Unpublished manuscript, University of Groningen.

Jackendoff, Ray. 1971. Gapping and Related Rules. Linguistic Inquiry 2:21-36.

Johannessen, Janne Bondi. 2005. The Syntax of Correlative Adverbs. Lingua 115: 419-443.

Kucerova, Ivona. (in press). An Anti-Intervention Effect in Czech Splits: An Argument for Late Merge. Proceedings of Formal Approaches to Slavic Languages 15.

Larson, Richard. 1985. On the Syntax of Disjunction Scope. Natural Language and Linguistic Theory 3:217-264.

Malchukov, Andrej. 2004. Towards a Semantic Typology of Adversative and Contrast Marking. Journal of Semantics 21:177-198.

Munn, Alan. 1999. On the Identity Requirement of ATB Extraction. Natural Language Semantics 7:421-425.

Pesetsky, David. 2000. Phrasal Movement and its Kin. Cambridge, MA: MIT Press.

Ross, John. R. 1967. Constraints on Variables in Syntax. Ph.D. diss., Massachusetts Institute of Technology.

University of Washington

Department of Linguistics

P.O. Box 354340

Seattle, WA 98195-4340

bcitko@u.washington.edu 